\title{
AN ARDUINO BASED HOME AUTOMATION SYSTEM
}

\author{
M.Harish, K.Neeraja Santoshi Lakshmi, T.Niharika \\ Department of ECE, Amrita Vishwa Vidyapeetham, Bangalore \\ harish.reddy93@gmail.com, iamsantoshi.nsl@gmail.com, santha.haari@gmail.com
}

\begin{abstract}
:
Security is becoming an important issue everywhere. Home security is becoming necessary nowadays as the possibilities of intrusion are increasing day by day. Safety from theft, leaking of raw gas and fire are the most important requirements of home security system for people. A traditional home security system gives the signals in terms of alarm. However, the GSM (Global System for Mobile communications) based security systems provides enhanced security as whenever a signal from sensor occurs, a text message is sent to a desired number to take necessary actions. This project mainly focuses on the security of a home when the user is away from the place.
\end{abstract}

Index terms: ARDUINO, GSM, AT commands

\section{Introduction}

Home automation can offer many benefits and free the users from the burden of having to care if energy is being used rationally, if savings are taking place or if waste is being avoided. In this system Arduino is the heart of this system which takes control over whole the system process. Here a GSM module is used for sending and receiving the message.

In this project, devices like fan, bulb, etc., are controlled using GSM Module. Arduino is a open source electronics prototyping platform based on flexible, easy-to-use hardware and software. It's an open-source physical computing platform based on a microcontroller board, and a development environment for writing software for the board. Using GSM Module, we can make devices ON/OFF with just a simple SMS. Home automation is automation of the household activities. It may include centralized control of lighting, HVAC (heating, ventilation and air conditioning), appliances, and other systems, to provide improved convenience, comfort, energy efficiency and security [4]. Conventional security systems keep homeowners, and their property, safe from intruders by giving the indication in terms of alarm [7].
The concept of home automation has been around for a long time and products have been on the market for decades [4]. Integrating the home systems allows them to communicate with one another through the home controller, thereby enabling single button and voice control of the various home systems simultaneously, in pre-programmed scenarios or operating modes [10]. Home automation for the elderly and disabled can provide increased quality of life for persons who might otherwise require institutional care. It can also provide a remote interface to home appliances or the automation system itself, via telephone line, wireless transmission or the internet, to provide control and monitoring via a smart phone or web browser [4]. In this project, a GSM modem (SIM900A) is selected to connect to a remote user via AT commands for sending and receiving SMS. Basically motion is detected in the web cam range and if found it will send photos to the user in the form of e-mails. It also monitors environmental variables (e.g. Temperature \& light) continuously and information of any change in environment i.e. increase in temperature or decrease in light intensity is sent via SMS using GSM network. When the user replies in a specific format using SMS, the information is processed and proper actions are taken accordingly. For example if temperature increases to a specified limit, then an SMS is sent to the remote user regarding the situation. The user then replies for switching on the appliance as required.

\section{AT Commands}

AT commands are instructions used to control a modem. AT is the abbreviation of Attention. Every command line starts with "AT" or "at". That's why modem commands are called AT commands. Many of the commands that are used to control wired dial-up modems, such as ATD (Dial), ATA 
(Answer), ATH (Hook control) and ATO (Return to online data state), are also supported by GSM/GPRS modems and mobile phones. Besides this common AT command set, GSM/GPRS modems and mobile phones support an AT command set that is specific to the GSM technology, which includes SMS-related commands like AT+CMGS (Send SMS message), AT+CMSS (Send SMS message from storage), AT+CMGL (List SMS messages) and AT+CMGR (Read SMS messages). The starting "AT" is the prefix that informs the modem about the start of a command line. It is not part of the AT command name. For example, D is the actual AT command name in ATD and +CMGS is the actual AT command name in AT+CMGS.

\section{Methodology}

This project is divided into two modules for home security system. Fig.1 comprehensively explains the methodology followed in this paper. The first module uses web camera. Whenever there is a motion in front of the camera, it gives security alert by sending mail to the owner. The second module is designed such that it sends SMS which uses GSM Module, Arduino, sensors. This project mainly focuses on the security of a home when the user is away from the place.

\section{Module1:}

The security system uses a web camera, installed in house premises, which is operated by Yawcam software installed on the PC and it uses Internet for communication. The camera detects motion of any person in front of the camera dimensions or camera range. The software communicates with the user via Internet network. Whenever there is a motion in front of camera or in its range, it captures pictures and to the user in the form of e-mail. The user will act accordingly and will give the command to open the door if he wishes to allow that person, through cell phone to SIM number fed in the GSM modem. The GSM modem will forward the command to Arduino to trigger the solenoid enabling the door to open and close.

\section{Module2:}

The second security system is SMS based and uses GSM technology to send the SMS to the owner. The proposed system is aimed at the security of Home against Intruders and Fire. The system is made up of three components: sensors, GSM Module, Arduino to control the device. It consists of sensors like temperature sensor (LM 35), light sensor (LDR). Home appliances like LED lights and fans are also connected to make the home energy efficient. The proposed system is controlled by a Arduino. It collects information from the sensors, makes a decision and sends SMS to a corresponding number by using GSM modem (SIM 900A). If it finds any interruption in its sensors then Arduino will send a SMS to the home owner. In the same way, if the temperature is increased above certain point which is specified in the program, it switch ON the fan automatically and a SMS will be sent to the home owner 'HIGH TEMPERATURE' giving the indication. After the temperature falls below specified range it switches OFF the fan and sends an SMS to the user indicating controlled temperature. The LDR (Light Dependent Resistor) is used to sense the light in a room. If the light intensity is above specified level, it sends an SMS to the user indicating that light is ON. Then the user sends command to switch OFF the light to Arduino and accordingly lights will be turn $\mathrm{ON}$ or OFF.

\section{Block diagram:}

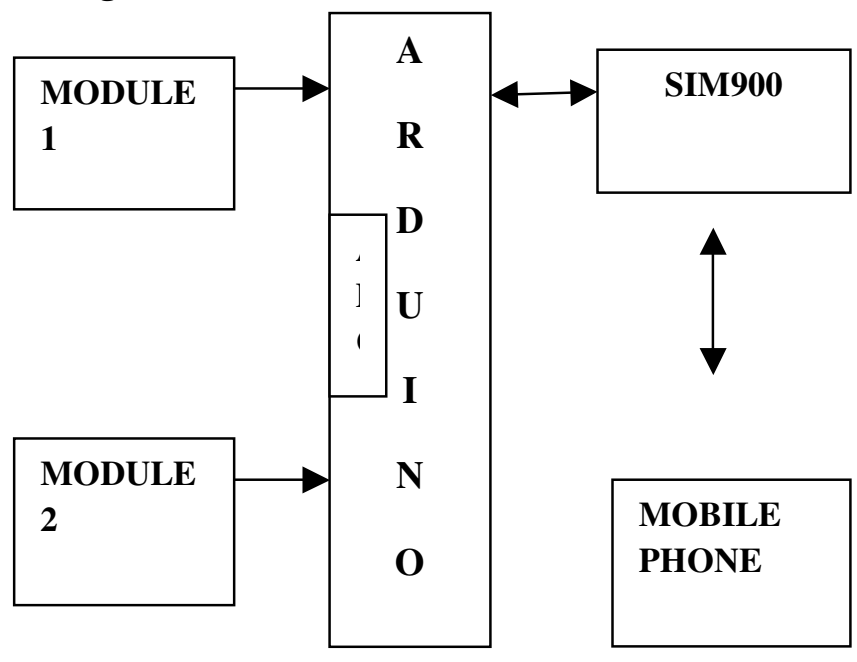

Fig.1 Block diagram of Arduino based home automation system

\section{Conclusion}

Different techniques for home automation system have been surveyed. Different author gives various techniques with block diagram, flowchart and their explanation with proper layout of successful execution with adequate strengths and weaknesses. All systems are designed in this surveyed papers are designed and tested practically. Main purpose of this method of implementation is that all systems are in hazardous condition, henceforth it is useful for old aged and handicapped persons and save electricity, time, money etc.

\section{Acknowledgement}

We would like to begin with offering our sincere regards to Amrita Vishwa Vidyapeetham and to The Chancellor, our beloved Amma without whose grace we wouldn't have treached this stage. 
We are grateful to Dr.Rakesh S.G, Associate Dean, for providing us with the great opportunity of doing our final year project in ASE, Bangalore.

We are thankful to Dr. Shika Tripathi, Head of Department for Electronics and Communication, Amrita School of Engineering, for her support.

We extend our sincere gratitude to Ms. Jayashree M Oli, Assistant professor, Department of Electronics and Communication, ASE Bangalore for mentoring us and providing moral support throughout the course of the project.

We would like to take this opportunity to wholeheartedly thank our teachers from the Department of Electronics \& Communication, Amrita School of Engineering for their constant guidance.

\section{References}

1. Aisha Jilani, Sahar Sultan, Intesar Ahmed and Sajjad Rabbani, "Management of Home Appliances with variation in temperature", IJEIT, volume 4, Issue 2,August 2014.

2. Ofoegbu Edward $\mathrm{O}$ and Ogunmakinde Olabode E, "A Microcontroller Based Building Automation System for real time Sensing and Control", International Journal of Innovation and Scientific Research, Vol. 2, June 2014.

3. Roopa K N, Ms. Savitha Patil,”A zigbee based smart sensing platform for monitoring environmental conditions in indoor stations”,IJCRD, volume 2, Issue 5, May2014.

4. Deepali Javale, Mohd. Mohsin, Shreerang Nandanwar, Mayur Shingate, "Home Automation and Security System Using Android ADK", International Journal of Electronics Communication and Computer Technology (IJECCT), Volume 3, Issue 2, March 2013.

5. Nwankwo Prince.N, Nsionu Ifeanyi.I, Ezeilo Chiegboka Joseph,"Design and implimentation of microcontroller based security door system", Journal of automation and control engineering, volume 1, no.1, March 2013.

6. Ushie James Ogri, Donatus Enang Bassey Okwong, Akaiso Etim," DESIGN AND CONSTRUCTION OF DOOR LOCKING SECURITY SYSTEM USING GSM", International Journal Of Engineering And Computer Science,Volume 2, Issue 7 (July 2013), Page No. 2235-2257.

7. Jayashri Bangali, Arvind Shaligram,"Design and Implementation of Security Systems for Smart Home based on GSM technology ", International Journal of Smart Home, Vol.7, No.6 (2013), pp.201-208.

8. Ashish Jadhav, Mahesh Kumbhar, Mahesh Walunjkar, “ Feasibility Study of Implementation of Cell Phone Controlled, Password Protected Door Locking System", International Journal of Innovative Research in Computer and Communication Engineering, Vol. 1, Issue 6, August 2013.

9. Nikhil Agarwal ,G.Subramanya Nayak ," Microcontroller based Home Security System with Remote Monitoring”, International
Conference on Electronic Design and Signal Processing (ICEDSP) 2012

10. Rosslin John Robles, Tai-hoon Kim, "Applications, Systems and Methods in Smart Home Technology: A Review", International Journal of Advanced Science and Technology, Vol. 15, February, 2010 